\title{
Correction to: Towards Expeditionary Battlefield Manufacturing Using Recycled, Reclaimed, and Scrap Materials
}

\author{
MARC PEPI, ${ }^{1,2}$ NICOLE ZANDER, ${ }^{1}$ and MARGARET GILLAN ${ }^{1}$ \\ 1.-US Army Research Laboratory, Aberdeen Proving Ground, Aberdeen, MD 21005, USA. \\ 2.—e-mail: marc.s.pepi.civ@mail.mil
}

\section{Correction to:}

JOM, Vol. 70, No. 10, 2018

https://doi.org/10.1007/s11837-018-3040-8

A significant portion of duplicate content from this article was published as "Manufacturing at the Point of Need Using Recycled, Reclaimed, and/or Indigenous Materials," by Marc Pepi, Nicole Zander, Margaret Gillan, in DSIAC Journal, Vol. 5, No. 3,2018 . DSIAC is a publication of the United States
Defense Systems Information Analysis Center, whose content is approved for public release and whose distribution is unlimited.

JOM editors were unaware of the previous publication at the time of acceptance.

Publisher's Note Springer Nature remains neutral with regard to jurisdictional claims in published maps and institutional affiliations. 